\title{
Sulphur and cystine incorporation into rumen microbial protein
}

\author{
By N. P. McMENIMAN,* D. BEN-GHEDALIA† AND R. ELLIOTT \\ Department of Agricultural Biochemistry, University of Newcastle upon \\ Tyne, Newcastle upon Tyne $N E_{\mathrm{I}}{ }_{7} R U$
}

(Received 29 fuly 1976 - Accepted Iо August 1976)

\begin{abstract}
I. In three series of experiments, $\mathrm{Na}_{2}{ }^{35} \mathrm{SO}_{4}$ was infused into the rumen of sheep consuming a variety of diets. The specific activity of the sulphur in the rumen $\mathrm{H}_{2} \mathrm{~S}$ pool, rumen bacteria and of the $\mathrm{S}$ in bacterial cystine were determined.

2. The results showed that, depending upon the diet, the proportion of total sulphur and cystine sulphur in rumen bacteria originating in the rumen $\mathrm{H}_{2} \mathrm{~S}$ pool could be as low as 0.557 and 0.280 respectively.
\end{abstract}

Although it has been shown that a few rumen bacteria require amino acids which contain sulphur for growth (Pittman \& Bryant, 1964), the current opinion is that sulphide is the primary source of $\mathbf{S}$ for bacterial protein synthesis and that amino acids containing $\mathrm{S}$ are synthesized de novo from this substrate (see Moir, 1969). Evidence in support of this view was provided by Nader $\&$ Walker (1970) who showed in rumen studies in vitro that there was little direct incorporation of cyst(e)ine or methionine into bacterial protein. Recently, however, Gawthorne \& Nader (1976) reported the extent of direct incorporation of sulphur amino acids by rumen microorganisms, in vivo, to be greater than generally believed.

Because of the increasing importance of ${ }^{35} \mathrm{~S}$ as a rumen microbial marker (Beever, Harrison, Thomson, Cammell \& Osbourn, 1974; Hume, 1974) we have studied in vivo the incorporation of sulphide and cystine $\mathrm{S}$ into rumen microbial protein.

\section{EXPERIMENTAL}

\section{Sheep and their management}

Three series of experiments were conducted and in each of them sheep equipped with rumen cannulae were used. The sheep were housed in metabolism cages and their respective diets were given in equal quantities at hourly intervals. The diets given are summarized in Table $\mathbf{r}$.

In all experiments, between $\mathrm{I}$ and $\mathrm{I} \cdot 5 \mathrm{mCi}$ of ${ }^{35} \mathrm{~S}$ as $\mathrm{Na}_{2}{ }^{35} \mathrm{SO}_{4}$, in 21 of glassdistilled water, was infused into the rumen of each sheep via the cap in the rumen cannula. Each infusion was continued for a $72 \mathrm{~h}$ period to ensure steady-state condi-

\footnotetext{
* Present address : Pastoral Laboratory, Department of Primary Industries, P.O. Box 282, Charleville, Queensland, 4470, Australia.

$\dagger$ Present address: Department of Animal Nutrition, Faculty of Agriculture, The Hebrew University of Jerusalem, P.O. Box I2, Rehovot, Israel.

$\ddagger$ Present address: Boots Research Station, The Priory, Thurgarton, Nottinghamshire.
} 
Table I. The diets fed to the sheep

\begin{tabular}{|c|c|c|c|c|c|}
\hline Diet & $\begin{array}{l}\text { Expt } \\
\text { no. }\end{array}$ & $\begin{array}{l}\text { No. of } \\
\text { sheep }\end{array}$ & $\begin{array}{l}\text { Nitrogen in } \\
\text { diet } \\
(\mathrm{g} / \mathrm{IO0} \mathrm{g} \mathrm{DM})\end{array}$ & $\begin{array}{l}\text { Source of nitrogen } \\
\text { in diet }\end{array}$ & $\begin{array}{c}\text { Intake } \\
(\mathrm{g} \mathrm{DM} / 24 \mathrm{~h})\end{array}$ \\
\hline $\begin{array}{l}\text { Series I } \\
\quad \text { Purified }\end{array}$ & $\mathbf{x}$ & I & 2.08 & 9 parts urea, & 600 \\
\hline Purified & 2 & I & 2.08 & $\begin{array}{l}9 \text { parts urea, } \\
\text { I part maize } \\
\text { gluten }\end{array}$ & 600 \\
\hline Pelleted grass & 3 & I & $2 \cdot 16]$ & & 700 \\
\hline Pelleted grass & 4 & I & 3.14 & Pelleted grass & 600 \\
\hline Pelleted grass & 5 & I & 3.14 & & 400 \\
\hline \multicolumn{6}{|l|}{ Series 2} \\
\hline Purified & 6 & 3 & $2 \cdot 08$ & Urea & 600 \\
\hline Purified & 7 & 3 & $2 \cdot 08$ & Maize gluten & 600 \\
\hline \multicolumn{6}{|l|}{ Series 3} \\
\hline $\begin{array}{l}\text { Semi-purified plus } \\
\text { unheated beans } \\
\text { (Vicia faba) }\end{array}$ & 8 & 3 & $2 \cdot 26$ & $\begin{array}{l}6 \text { parts urea, } \\
4 \text { parts beans }\end{array}$ & 768 \\
\hline $\begin{array}{l}\text { Semi-purified plus } \\
\text { heated beans } \\
\text { (Vicia faba) }\end{array}$ & 9 & 3 & $2 \cdot 26$ & $\begin{array}{l}6 \text { parts urea, } \\
4 \text { parts beans }\end{array}$ & 768 \\
\hline
\end{tabular}

tions in the rumen before samples were taken. The samples of rumen liquor for the determination of the specific activity of $\mathrm{S}$ in rumen $\mathrm{H}_{2} \mathrm{~S}$ were withdrawn into sealed syringes via a tube passing through the cannula; six samples were obtained per animal. Approximately $\mathrm{I} 1$ of rumen liquor was then taken from the rumen and strained through four layers of cheesecloth. To remove the protozoa, the rumen liquor was placed in a separating flask and left in an incubator for $20 \mathrm{~min}$ at $40^{\circ}$. The protozoa settled out and could be removed. The liquor was centrifuged at $2500 \mathrm{~g}$ for $20 \mathrm{~min}$ to remove any remaining food particles. The microbial residues in suspension were then collected by centrifugation at $35000 \mathrm{~g}$ for $30 \mathrm{~min}$.

The cells were dispersed and washed prior to recentrifugation. This process was repeated once more. After freeze drying, the bacterial fraction was ground and stored at room temperature.

\section{Analyses}

Sulphides in rumen liquor and the total non-volatile $\mathrm{S}$ content of bacterial and protozoal samples were determined titrimetrically by the method of Bird \& Fountain (1970). Before the titration step, however, an aliquot of the absorbing solution (I M$\mathrm{NaOH}$ ) was obtained for subsequent counting.

Total non-volatile $\mathrm{S}$ in each bacterial and protozoal sample was oxidized to sulphate by heating the sample at $55^{\circ}$ for $5 \mathrm{~h}$ with an oxidizing mixture (25 parts $\mathrm{NaHCO}_{3}$ to I part $\mathrm{Ag}_{2} \mathrm{O}$ ). Sulphate was then released as $\mathrm{H}_{2} \mathrm{~S}$ into a stream of nitrogen gas by heating the oxidized sample in a reduction mixture (4 parts hydriodic acid, 2 parts formic acid and I part hypophosphorous acid) for $15 \mathrm{~min}$. The estimation of released $\mathrm{H}_{2} \mathrm{~S}$ was as previously described.

Cystine S in bacteria and protozoa was determined by the method of Elliott (1975). 
Table 2. The proportion* of total and cystine sulphur in rumen bacteria and protozoa that originated in the rumen $\mathrm{H}_{2} \mathrm{~S}$ pool

$\begin{array}{cccc}\begin{array}{ccc}\text { Expt no. } \\ \text { Series I }\end{array} & \begin{array}{c}\text { Bacteria } \\ \text { I }\end{array} & \begin{array}{c}\text { Pystine S } \\ \text { bacteria }\end{array} \\ 2 & 1.009 & 0.914 & - \\ 3 & 1.005 & 0.971 & - \\ 4 & 0.834 & 0.705 & - \\ 5 & 0.623 & 0.427 & - \\ \text { Series 2 } & 0.697 & 0.500 & - \\ 6 & & & - \\ 7 & 1.004 \pm 0.022 & - & \\ \text { Series 3 } & 0.557 \pm 0.020 & - & 0.425 \pm 0.020 \\ 8 & & - & 0.280 \pm 0.014 \\ 9 & 0.715 \pm 0.016 & \end{array}$

The aliquot of absorbing solution for the determination of radioactive $\mathbf{S}$ was obtained before the addition of the $p$-amino dimethylalanine solution. Radioactivity was determined by adding the respective aliquots (each $\mathrm{I} \mathrm{ml}$ ) to $\mathrm{Io} \mathrm{ml}$ of scintillant (NE 260 , Nuclear Enterprises, Edinburgh) and the number of counts in 20 min determined using a Beckman liquid scintillation spectrometer. The specific activity of a sample was defined as the number of counts in the sample divided by the $\mathrm{S}$ content. $\mathrm{N}$ in the diets was determined using the Kjeldahl procedure.

\section{RESULTS AND DISCUSSION}

If all of the $\mathrm{S}$-containing amino acids in rumen bacteria were synthesized de novo from the sulphide pool then the specific activity of the $S$ in this pool and in the total $S$ of bacteria could be expected to be the same. From the results presented in Table 2, it can be seen that this was the case when the diets offered contained little (Expts I and 2) or no (Expt 6) preformed amino acid N. However, when the sheep were fed grass nuts (Expts 3,4 and 5) which contained a much higher proportion of natural protein, the amount of $\mathrm{S}$ in bacteria which originated in the $\mathrm{H}_{2} \mathrm{~S}$ pool was much lower; this effect can also be seen when maize gluten was the sole source of $\mathrm{N}$ in the diet (Expt 7). It is interesting to note that of the pelleted grass diets the one with the highest level of incorporation of sulphide $\mathbf{S}$ into bacteria (Expt 3) contained the lower level of dietary $\mathrm{N}$.

The results showed that when preformed amino acids were abundant in the diet the bacteria directly incorporated preformed S-containing compounds, presumably peptides and/or amino acids, and that the level of incorporation was influenced by the concentration of protein in the diet. It is probable, however, that the solubility of the protein would have influenced this latter effect. With protozoa the proportion of sulphide $\mathrm{S}$ incorporated was always lower than that recorded for the respective 
bacterial sample. As protozoa obtain their amino acid requirements by engulfing undigested food protein and bacterial protein (Coleman, 1975) the above results would be expected.

In the third series of experiments it was shown that rumen bacteria can obtain a large proportion of their cystine $S$ from sources other than the sulphide pool. In Expts 8 and 9 (Table 2) less sulphide $\mathrm{S}$ was incorporated into bacterial cystine than into bacterial total S. As the analytical technique used for the detection of cystine (Elliott, I975) only quantifies the $\mathrm{S}$ in this amino acid it cannot be definitely concluded that the bacteria directly incorporated dietary cystine; however, the inference must be that this did occur. The alternative explanation is that all of the bacterial cystine was synthesized de novo and that the sulphur was incorporated into this cystine without going through the sulphide pool. Nolan \& Leng (1972) used ${ }^{15} \mathrm{~N}$ with sheep fed lucerne chaff and found that approximately $29 \%$ of the $\mathrm{N}$ digested in the rumen was directly incorporated as amino acid $\mathrm{N}$ into bacteria and similar levels of incorporation can be inferred from other reports (Pilgrim, Gray, Weller \& Belling, I970; Mathison \& Milligan, r97I).

The results presented above show that when diets containing appreciable quantities of preformed amino acids were fed to sheep, up to $44 \%$ of the total S and $72 \%$ of the cystine $\mathrm{S}$ incorporated into rumen bacteria were not derived from the rumen sulphide pool.

\section{REFERENCES}

Beever, D. E., Harrison, D. G., Thomson, D. J., Cammell, S. B. \& Osbourn, D. F. (1974). Br. F. Nutr 32, 99.

Bird, P. R. \& Fountain, R. D. (1970). Analyst. 95, 98.

Coleman, G. S. (1975). In Digestion and Metabolism in the Ruminant, p. I49 [T. W. McDonald and A. C. I. Warner, editors]. University of New England (Australia) Publ. Unit.

Elliott, R. (1975). Newsletter on the Application of Nuclear Methods to Biology and Agriculture, no. 5, p. 6.

Gawthorne, J. M. \& Nader, C. J. (1976). Br. F. Nutr. 35, I I.

Hume, I. D. (1974). Aust. $\mathcal{F}$. agric. Res. 25, 155.

Mathison, G. W. \& Milligan, L. P. (1971). Br. F. Nutr. 25, 351.

Moir, R. J. (1969). In Symposium of Sulphur in Nutrition, p. I6 5 [O. H. Muth, editor]. Westport, Connecticut: A.V.I. Publ. Co. Inc.

Nader, C. J. \& Walker, D. J. (1970). Appl. Microbiol. 20, 677.

Nolan, J. V. \& Leng, R. A. (1972). Br. F. Nutr. 27, I77.

Pilgrim, A. F., Gray, F. V., Weller, R. A. \& Belling, C. B. (1970). Br. F. Nutr. 24, 589.

Pittman, K. A. \& Bryant, M. A. (1964). F. Bacteriol. 88, $40 \mathrm{r}$. 